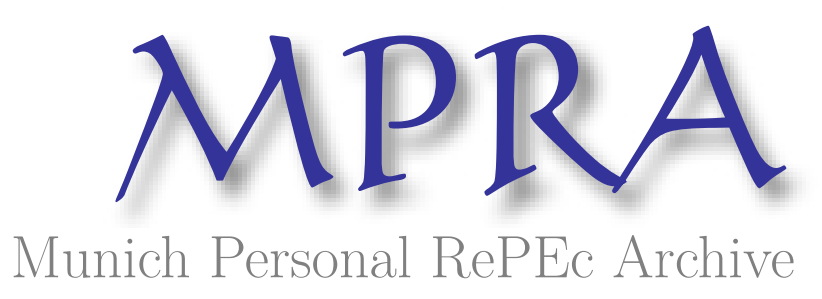

\title{
The Benefits of Reducing Hold-Out Risk: Evidence from the Euro CAC Experiment, 2013-2018
}

Picarelli, Mattia and Erce, Aitor

21 November 2018

Online at https://mpra.ub.uni-muenchen.de/89973/

MPRA Paper No. 89973, posted 22 Nov 2018 07:41 UTC 


\title{
The Benefits of Reducing Hold-Out Risk: Evidence from the Euro CAC Experiment, 2013-2018*
}

\author{
Mattia Osvaldo Picarelli, ${ }^{\bullet+}$ \\ Aitor Erce \\ Xu Jiang
}

\begin{abstract}
The introduction of collective action clauses in advanced economies' sovereign bonds is an understudied phenomenon. An important concern is whether these clauses produce segmentation, pushing apart the price of those bonds issued with and without collective action clauses (CACs). This paper uses the introduction in 2013 of mandatory two-limb CACs in euro area sovereign bonds issued under domestic law to evaluate the price impact of these provisions. In the euro area, bonds with CACs trade at a small premium. On average for those bonds, yields were up to six basis points lower. This average, however, masks heterogeneity. While Germany and Netherlands have not seen a sustained reduction in borrowing costs, in Italy and Spain the effect has been large (between five and ten basis points). These findings support the argument that the introduction of euro CACs in domestic law bonds helped investors reassess the risks associated with those instruments in both countries.
\end{abstract}

Keywords: Collective action clause, hold-outs, sovereign risk, bond yields.

JEL Codes: F34, H63, K41

\footnotetext{
We wish to thank Roel Beetsma, Pedro Bizarro, Stefano Finesi, Mitu Gulati, Adrian Kaeser, Jenny Sellin, Lluis Sanchis, Sheetal Tewari, Silke Weiss, two anonymous referees, and seminar participants at the European Stability Mechanism for helpful comments, and Sharman Esarey for excellent editorial support. The views in this paper are the authors' and are not to be reported as those of the European Stability Mechanism.

* Corresponding author (M. Picarelli): M.OsvaldoPicarelli@esm.europa.eu.

- European Stability Mechanism.
} 


\section{Introduction}

The economic dislocation accompanying sovereign debt defaults worsens the longer it takes debtors and creditors to find a negotiated solution (House et al., 2017; Schumacher et al. 2018). ${ }^{1}$ History shows that rogue creditors (also known as hold-out creditors) have often blocked restructuring processes, making these unnecessarily protracted and painful (Aguiar and Amador, 2014; Zettelmeyer, 2018). In reaction, the international community has over time developed tools to minimize the costs created by these hold-out creditors. These include official procedures to unlock official lending (like the IMF's lending into arrears policy), codes of conduct, and legal remedies in the form of clauses introduced into bond contracts. ${ }^{2}$ Within the last, collective action clauses (CAC), which are meant to facilitate debt workouts by removing the unanimity requirement to agree on a restructuring, have gained prominence (Gelpern, 2015). Following the global crisis, governments began to add new collective action clauses to their bonds. In this paper, we study the impact of these innovations on the pricing of sovereign bonds.

Collective action clauses became popular in the early 2000s as the debate on how to tackle sovereign debt crisis tilted away from a statutory (Krueger, 2002) toward a market-based regime (Taylor, 2002). Traditional CACs allow for changes in the terms of bond contracts, based on approval by a majority of bondholders in terms of outstanding principal. Two-thirds or three-quarters majorities are often seen as reasonable thresholds. In reaction to the euro area crisis, as part of the setting up of the European Stability Mechanism, euro area countries agreed to include in all new sovereign bonds CACs (see Article 12(3) of the ESM Treaty). ${ }^{3}$ The EA Model CAC (euro CAC) departed from the earlier model by lowering to two-thirds the majority needed at the level of each bond to approve a proposed amendment (counted as the aggregate principal amount of the outstanding debt securities of affected series capable of aggregation). ${ }^{4}$ The euro CAC also contains an additional three-quarters majority, needed when counting all bonds targeted together (cross-series). Because of the dual majority requirement, this voting model is known as double-limb aggregation.

In 2014, the International Capital Markets Association proposed a new CAC (ICMA CAC) featuring a different aggregation technique. ${ }^{5}$ The ICMA CAC includes the possibility of using a unique aggregate vote across all bonds (single-limb), in addition to a lower approval threshold for the double-limb aggregation than under the euro CAC. ${ }^{6}$ This single-limb aggregation mechanism replaces the double threshold requirement with a single vote (subject to a majority of at least $75 \%$ ) across all series, with no majority needed at the bond level. ${ }^{7}$

\footnotetext{
${ }^{1}$ See Pitchford and Wright (2012) for a theoretical model on debt restructuring delays and the role of CACs.

2 Introducing explicit safeguards in bond documentation is the globally accepted market-based approach to debt restructuring. Legal practice has focused on: contract provisions relating to equal treatment of creditors (pari-passu and cross-default), and clauses setting voting rules for changing reserved matters.

${ }^{3}$ A specific design of CACs was agreed separately and implemented individually by each issuer.

${ }^{4}$ CACs contain two different thresholds under two-limb aggregation: 1) if the decision is approved in a meeting and 2) if it is passed by a written resolution signed on behalf of a majority of note-holders. The majorities are different in the two cases: $2 / 3$ of votes cast in a meeting (meaning that abstentions are ignored) or $50 \%+1$ of outstanding principal signing a written resolution (meaning that whoever doesn't sign is counted as a no vote).

${ }^{5}$ In October 2014, Kazakhstan was the first country to issue a bond with the new ICMA CAC (Gelpern et al., 2015).

${ }^{6}$ More specifically, ICMA CACs apply the majority requirements of written resolutions under current CACs to meetings.

${ }^{7}$ In reaction to the issues faced by Argentina at the time, ICMA (2014) also provided a new drafting for pari-passu clauses.
} 
Given that double-limb aggregation may not prevent bondholders from obtaining blocking positions in specific bonds, there is an ongoing debate within the euro area regarding the convenience of adding ICMA-like CACs to the documentation of sovereign bonds (Zettelmeyer, 2018; Andritzky et al. 2018). Those in favour argue this would reduce uncertainty and provide incentives to buy these bonds. Those against highlight the negative signalling (potential defaults) and liquidity effects. ${ }^{8}$ Remarkably, this debate proceeds with limited empirical evidence.

An important consideration regards the underlying legal system into which the CACs are introduced (Schumacher et al., forthcoming). While, originally, CACs were introduced in foreign law instruments with the aim to reduce the hold-out problem, their role can radically different in domestic law obligations (Buchheit et al. 2013). Indeed, under domestic law, CACs are not necessary to restructure sovereign debt. The government can do it through a legislative act. In this context, the introduction of CACs might help reassuring investors by reducing government discretion (Carletti et al., 2018). ${ }^{9}$

This paper contributes to filling this analytical gap with two separate sets of evidence: one for euro CAC in domestic law issuances and another for ICMA CAC in foreign law issuances. To evaluate the impact of two-limbed CAC structures on euro area governments borrowing costs, we follow the work of Carletti et al. (2018). As they do, we combine a matching technique with panel regressions. To provide additional insights we extend the sample data up until 2018 (theirs stops in 2015). Given that various transitory factors could affect the effect of the CACs overtime, our larger sample allows us to test whether the effects of CACs have changed over time. ${ }^{10}$ Moreover, thanks to the larger pool of bonds and observations at our disposal, we study country-specific time-varying effects of the CACs. Additionally, while Carletti et al. (2018) match bonds with differences in remaining maturities of up to three years, we use an alternative (tighter) matching, with a narrower remaining maturity window (one year) to match the bonds, and also limit the difference between matches as regards coupons (below 5 percent) and original maturity at issuance (not more than ten years difference). ${ }^{11}$

In line with the findings in Carletti et al. (2018), our evidence shows that the dual-limbed euro CACs reduce borrowing costs; with the caveat that there is heterogeneity across countries. Of particular interest, we find a large effect in both Italian and Spanish bond markets. In both cases, there is scope to argue that the inclusion of the CACs led investors to feel an increased degree of protection over a redenomination risk and the domestic legal character of the bonds. ${ }^{12}$

Our evaluation of the pricing impact of single-limb CACs takes advantage of the fact that Sweden introduced the new ICMA CAC in 2017. Evidence on the effect of single-limb structures is not easy to

\footnotetext{
${ }^{8}$ CACs create segmentation in sovereign bond markets (Cannata, 2018). Bonds of the same issuer but with different CACs provisions might not be seen as perfectly fungible from a credit perspective, influencing secondary market liquidity.

${ }^{9}$ According to the findings in Carletti et al. (2018) this is the case for issuers with strong legal institutions.

${ }^{10}$ According to Ratha et al. (2018) these transitory effects could include first issue effects and changes in the investor base of the bonds. Additionally, given that the larger proportion of debt with CACs the likelier these will be effective, one could think that the dynamics of the proportion of debt with CACs also matter for their effect.

${ }^{11}$ This choice is motivated by the fact that bonds with very different coupons and or original maturities may be viewed differently by market participants, even when their remaining maturity is not too different. One reason why very different coupons can make bonds look different is that they affect the sensitivity of duration to changes in interest rates. In turn, bonds issued with long maturities are often acquired by buy-and-hold investors (see Feldman et al. (2015)). As a result, these bonds remain structurally different than shorter bonds, even when their remaining maturity becomes shorter.

${ }^{12}$ We note that the large effect on Italy from the introduction of CACs may be the result of the euro CACs reducing the uncertainty related to the possibility of using a unilateral maturity extension embedded in some bonds (Edelen et al., 2012). We note, however, that this is an Italian law provision, not a clause directly embedded in the terms of the bonds.
} 
find even though these new clauses have already been adopted by several emerging market economies (Zandstra, 2017). Our results for Sweden point to a small effect from shifting to a singlelimb aggregated CAC in foreign-law sovereign bonds, roughly below one basis point. ${ }^{13}$ While these findings are robust to different specifications, the few bonds and short time series available suggest caution is necessary in drawing conclusions from them.

The rest of this paper is organized as follows. Section 2 reviews the existing literature related to CAC provisions. Section 3 describes the euro area experience with the two-limb CACs and the related empirical analysis. Section 4 provides a preliminary evidence of the single-limb clause pricing effect for Sweden. Section 5 concludes.

\section{Literature Review}

As the role of contractual protection in managing sovereign risk has increased in recent decades, a growing body of empirical work has studied their effect on market dynamics. CACs seek to avoid that a minority of debtors blocks a restructuring operation (hold-out problem) and prevent legal action that can obstruct the process. In theory, while CACs support a fast restructuring process, driving yields down, they may also generate moral hazard, making default more likely, driving yields up. ${ }^{14}$ In this section we summarize the existing empirical literature, with a focus on double and single-limb aggregation clauses.

Early studies found little evidence of rising costs. Eichengreen and Portes (1995), Tsatsaronis (1999) and Eichengreen and Mody (2003), and Eichengreen and Mody (2004) study the effect of CACs assuming that bonds under English law always include them while those under NewYork law never do. ${ }^{15}$ In line with theories arguing that senior debt is harder to restructure and should trade at lower yields (Bolton and Jeanne, 2009), Tsatsaronis (1999) finds that CACs sometimes imply greater yields. Eichengreen and Mody $(2003,2004)$ show that CACs decrease borrowing costs for strong issuers and increase them for poorly-rated issuers. Becker et al. (2003); Richards and Giugiatti (2003) find that after controlling for creditworthiness CACs have a limited price impact.

More recent studies have had the benefit of more and better data. However, the results of these studies have not been consistent. Motivated by the innovations that followed the global crisis, Bradley and Gulati (2013) were able to code for specific vote thresholds, and control for the type of governing laws. They found CACs to slightly decrease the cost of borrowing, particularly for weaker sovereigns. Bardozzetti and Dottori (2014) found a similar effect, albeit for sovereign issuers with

\footnotetext{
13 Our results also point to traditional CACs increasing yields by about one third of a basis point.

${ }^{14}$ Theory does not provide a unique answer. While Haldane et al. (2005) show that CACs reduce the coordination problem and lower yields, Shleifer (2003) points to an opposite effect because CACs make restructuring easier. Ghosal and Thampanishvong (2013) show in a theoretical model with debtor moral hazard and creditor coordination problems that moving CACs threshold away from unanimity might reduce welfare.

${ }^{15}$ Originally, there were almost no bonds issued under New York-law without a unanimity requirement. Instead, most sovereign bonds issued under English-law allowed for contractual changes with less than unanimity. However, this kind of comparison was not taking into account two aspects of English-law bonds: 1) they did not have only the $75 \%$ vote threshold but they also required the physical meeting of bondholders (potentially exacerbating the holdout problem); 2) they had diminishing quorum requirements (Eichengreen and Mody, 2004).
} 
ratings in the middle of the scale. ${ }^{16}$ Ratha et al. (2018) find an ambiguous correlation between CACs and yields. In contrast with this evidence, focusing on the Venezuelan debt crisis, Carletti et al. (2016) provide evidence that passing from unanimity to CACs with a $75 \%$ of vote requirement produced higher yield (between $8.6 \%$ and $10.86 \%$ ). Instead, they find no pricing difference when the threshold was moved from $75 \%$ to $85 \% .{ }^{17}$ Scott et al. (2018), instead, found no evidence that different CAC provisions in Venezuela were priced differently, even close to default conditions. They claim that differences might show up after litigation-oriented funds initiate their legal action, as this is when the market can understand which bonds are targeted by holdout creditors.

Focusing on the euro area CACs introduced in domestic law bonds, early evidence comes from Fang (2015) and Steffen and Schumacher (2014). While Fang (2015) shows that CACs slightly increased borrowing costs for less creditworthy issuers, Schumacher (2014) found no significant effect coming from the euro CAC. In turn, Carletti et al. (2018) find that bonds with euro CACs trade at lower yields, and that the quality of the legal system matters for the size of this effect. Countries whose legal system is more efficient feature lower yields in bonds with CACs. This, they argue, supports the idea that CACs decrease the legal risk associated with sovereign debt issued under domestic legislation. Focusing on Italy alone, De Santis (2017) finds that bonds with CACs trade at marginally better prices, around 10 bps. These findings regarding domestic law bonds confirm the theory in Bolton and Jeanne (2009). Domestic bonds without CACs can be restructured simply by fiat. Therefore, they are easier to restructure than bonds including CACs, and should trade at a higher yield.

To date, given the lack of data (single-limb CACs are a relatively new phenomenon), there are no studies that we are aware of that examine the impact of single-limb collective action provisions. The only indication we have of their price impact is from the IMF, which reported on a preliminary basis in 2017, that the IMF staff had not perceived any observable impact of sovereign bond pricing from the introduction of single-limb CACs. ${ }^{18}$

\section{The euro area experience with two-limb CACs}

In 2003, as part of a coordinated initiative to promote collective action clauses, EU Member States decided to include them in their foreign-law bonds from 1 January 2004. These CACs stipulated that approval by a three-quarters majority of bondholders in each bond series would be needed to restructure the terms of that series (bond-by-bond). The issue then was seen as relevant for emerging economies, given that Euro area countries issued local-law bonds for the most part. The issue of CACs did not resurface until the global crisis hit the euro area. In November 2010, the Euro group agreed that standardised and identical CACs would be included in all new euro area government bonds. ${ }^{19}$ This obligation was codified in Article 12(3) of the ESM Treaty, which requires

\footnotetext{
${ }^{16}$ They argue this could be due to the fact that these sovereigns benefit most from an orderly restructuring, given they face a non-negligible probability of default (while the reputational cost of opportunistic behaviour is higher). Countries with higher ratings face such a low default probability that the impact from including CACs is negligible.

${ }^{17}$ One possible explanation is that the market might focus not only on different types of CACs but also on the strength of the pari passu clause embedded in the contract (Carletti et al., 2016).

${ }^{18}$ Results of surveys among public debt managers discussed in IMF (2017a) indicate that the inclusion of enhanced CACs has not had a pricing impact on new bond issuances. The available information suggests that market acceptance has been strong, yet the impact on pricing is considered to be rather insignificant.

${ }^{19}$ To preserve the liquidity of existing debt issues, issuers can tap existing securities up to a maximum per year.
} 
that the euro area Model CAC (euro CAC) be included in all securities with a tenor of more than one year, issued from 1 January 2013 onwards. ${ }^{20}$ The euro CAC departs from the post-2003 model by lowering to two-thirds of the outstanding principal the majority needed at the bond level to approve a proposed amendment. In contrast, it also requires a three-quarters majority when counting all targeted bonds together.

The rest of this section uses pre-sampling matching techniques and panel regressions to study the effect of the inclusion of euro CACs on the pricing of sovereign bonds. We first introduce the dataset we built for the analysis. Then we briefly explain the econometric strategy, and discuss our results. Tables with regression results and the larger figures are presented in the appendix.

\section{Data and Methodology}

Our evaluation of the effect of euro CACs extends the analysis in Carletti et al. (2018). As they do, we focus on sovereign bonds issued under domestic law and use matching and panel regression techniques to gauge the effect of the clauses. We deviate, however, in three critical aspects: we use a larger sample, a stricter matching and also target country-specific time-varying effects. We collected all CAC bonds issued after the introduction of CAC with a cut-off date of 7 September 2018, and no-CAC bonds issued before 1 January 2013 but maturing after that date ( 297 bonds in total). We obtained weekly information for all active and matured euro-denominated government bonds issued by euro area countries under domestic law, with/without CAC provisions, and maturity above one year from Bloomberg. ${ }^{21}$ Using the extracted ISIN from Bloomberg, we retrieved the governing law for each bond. In order to supplement the information on governing law (and crosscheck the information coming from Bloomberg), we applied the same filtering using the Dealogic database. We further narrowed down our bond sample to include only standard fixed coupon bonds. ${ }^{22}$ After applying these filters, we are left with 235 CAC bonds (see Table 2). We found no eligible bonds issued by Cyprus, Estonia, Greece, Latvia, Lithuania and Malta. ${ }^{23}$

\section{Bond matching}

To improve the estimation accuracy, as per Carletti et al. (2018), we pre-sample instruments that are sufficiently similar by applying a matching technique (Ho et al., 2007). This technique is used as a pre-screening instrument in order to select bonds. We construct two data samples: bonds with, and without, CAC provisions. We perform our matching by coupling each CAC bond in the CAC bonds pool with another no-CAC bond in the no-CAC bonds pool. The matching is based on three criteria: same issuer, same currency, and closest residual maturity. We then turn to the treatment and control groups we built for our analysis. We read Carletti et al. (2018) as placing no restriction on the maximum distance on residual maturity that the matching allows. This produces matches with up to three years difference. To achieve similar results, we adopt a strategy (henceforth loose matching)

\footnotetext{
20 Unlike in 2003, this law specifically envisioned applying the euro CAC to securities governed both by foreign and by domestic law.

${ }^{21}$ CACs are included only in bonds with maturity above one year. For that reason, we restrict our analysis to them.

${ }^{22}$ In addition, bonds with embedded options, such as convertible, sinkable, puttable and callable were excluded. Finally, we delete bonds issued for retail investors, issued by sovereign-backed agencies.

${ }^{23}$ Luxembourg, Slovakia and Slovenia are dropped because of limited price history. We also deleted a pair of Belgian bonds as the pricing history was incomplete.
} 
where we look for pairs of bonds with a difference in residual maturity between -3 and +3 years. This allows us to identify 201 pairs coming from Austria, Belgium, Finland, France, Germany, Ireland, Italy, Netherlands, Portugal and Spain (Table 2).

One concern with this matching approach is that market participants may not view bonds with such differences in residual maturity as comparable. ${ }^{24}$ Moreover, we further evaluate the quality of our matches by analysing how our matched bonds differ in two additional features critical to investors. As shown in Figure 1 and 2, we look at coupon and original maturity differences. We observe that some of our matches have large differences in these dimensions. Some matches feature coupon differences of up to eight percent, in others original maturities vary by as much as 25 years. To make sure that these differences are not affecting our estimates, we create a tighter set of matches. First, when performing the matching, we limit the maturity difference between the CAC and no-CAC bond to one year. In addition, we eliminate all matches in which the difference in coupons is more than five percent and all those where the difference in original maturity between the matched bonds is above 10 years. ${ }^{25}$

The final dataset includes 115 pairs for the following countries: Austria, Belgium, Finland, France, Germany, Italy, Netherlands and Spain. ${ }^{26}$ Table 2 in the appendix provides the country breakdown during each phase of data filtering and shows the maturity differential between CAC and no-CAC bonds in our sample. Some descriptive statistics of our sample are reported in Table 1. A similar message emerges from both samples. On average, CAC bonds have lower yields, lower durations and are more liquid (as reflected in lower bid-ask spreads).

Table 1: Summary statistics for the loose and tight sample - CACs and matched no-CACs bonds

\begin{tabular}{|c|c|c|c|c|c|}
\hline \multicolumn{6}{|c|}{ Loose sample } \\
\hline \multirow{2}{*}{ Variable } & \multicolumn{2}{|c|}{ CACs bonds } & \multicolumn{2}{|c|}{ Non-CACs bonds } & \multirow{2}{*}{ Diff. } \\
\hline & Mean & Std. Dev. & Mean & Std. Dev. & \\
\hline Yield & 73.12 & 112.71 & 120.99 & 142.27 & $47.87 * * *$ \\
\hline Duration & 7.01 & 4.24 & 7.48 & 4.33 & $0.47 * * *$ \\
\hline Liquidity & 0.03 & 0.24 & 0.22 & 2.96 & $0.19 * * *$ \\
\hline \multicolumn{6}{|c|}{ Tight sample } \\
\hline \multirow{2}{*}{ Variable } & \multicolumn{2}{|c|}{ CACs bonds } & \multicolumn{2}{|c|}{ Non-CACs bonds } & \multirow{2}{*}{ Diff. } \\
\hline & Mean & Std. Dev. & Mean & Std. Dev. & \\
\hline
\end{tabular}

\footnotetext{
${ }^{24}$ Given sovereign bonds markets are populated by investors that specialize in different segments of the curve, multi-year differences in maturity can generate differences in pricing due to differences in investor types. Along these lines, Ratha et al. (2018) and Choi et al. (2018) show that the pricing effect of CACs depends on the type of investors holding the bonds.

25 As already mentioned, bonds with long original maturities are often acquired by buy-and-hold investors, making them structurally different even as their remaining maturity shortens.

${ }^{26}$ Portugal and Ireland are removed from the sample as only one pair can be formed.
} 


\begin{tabular}{c|cc|cc|c}
\hline Yield & 65.28 & 111.90 & 110.52 & 140.28 & $45.24 * * *$ \\
\hline Duration & 6.12 & 3.35 & 6.45 & 3.31 & $0.33^{* * *}$ \\
\hline Liquidity & 0.03 & 0.27 & 0.26 & 3.24 & $0.22 * * *$ \\
\hline
\end{tabular}

Note: The table shows mean and standard deviation for our sample of CAC and no-CAC matched bonds. The last column reports the difference between the means of CAC and no-CAC bonds for each variable, together with the t-test on statistical significance. ${ }^{* * *}$ significant at $1 \%, * *$ at $5 \%$ and $* 10 \%$.

\section{Econometric analysis and discussion of results}

Following Carletti et al. (2018), we estimate our benchmark econometric model using pooled OLS with robust standard errors:

$$
y_{i, c, t}=\alpha+\beta \cdot C A C_{i}+\gamma \cdot \text { Controls }_{i, c, t}+\chi_{c}+\phi_{t}+\varepsilon_{i, c, t}
$$

where $y_{i, c, t}$ is the yield of bond i from country c, at time t. $C A C_{i}$ is a dummy variable that equals 1 for bonds including CACs and 0 otherwise. Controls $s_{i, c, t}$ is a vector of control variables including: credit ratings, to control for a country's creditworthiness, euro area 10-year government bond yield index to consider structural movements in sovereign bond yields, the bond's duration as a proxy for bond risk, the flow of bond purchases and stock of bond holdings by the ECB, and the bid-ask spread of the bond to control for liquidity. ${ }^{27} \chi_{c}$ stands for a set of country-fixed effect and $\phi_{t}$ contains weekly fixed-effects. Within this framework, the effect of including a collective action clause on a bond from country $\mathrm{c}$ is represented by $\beta .^{28}$

Table 4 contains the results. In all of our specifications controls are highly significant and mostly show the expected signs. ${ }^{29}$ Limiting the sample to 2013 and 2014, as in Carletti et al. (2018), we find that CAC provisions imply yields 11 bps to 6.5 bps lower, depending on whether we consider weekly and country fixed effects (column 2) or not (column 1). These coefficients remain highly significant but lower (5.3 and 4.45 bps) when we extend the sample until September 2018 adopting a loose matching (column 3 and 4). When we tight the matching, considering only one year difference in term of maturity date, maximum four percent difference in coupon rate and 10 years for original maturity, the values remain similar, highly significant and slightly lower (column 5 and 6). Given the predominance of Italian bonds in the sample, we run the same regression considering all the countries in our sample but Italy. The effect of CACs remains significant but it reduces by half.

This remarkable difference in the effect of CACs between Italy and the rest of our sample further motivates us to study the dynamic country-specific reaction to the introduction of CACs. We begin by producing country specific effects and then move to allow these effects to be time varying.

\footnotetext{
${ }^{27}$ We convert the rating into a numeric scale; with higher values representing higher ratings.

${ }^{28}$ All data are in weekly frequency.

${ }^{29}$ The coefficient associated with ECB purchases presents a positive sign, which we see as a reflection that purchases focus on the cheapest bonds available (see Nordea (2016)). We note here that given the purchase limits (33\% for non-CAC and $25 \%$ for $C A C$ ), the ECB is likely buying more non-CAC bonds, which should reduce their yields more than it does for CAC bonds.
} 


\section{Country-specific effects}

Taking advantage of our large sample of observations, we study the country-specific effect of CAC by running equation (1) separately for each country. ${ }^{30}$ Figure 3 depicts how the introduction of CACs seems to have produced heterogeneous country specific effects in both samples. In the loose matching the effect is always yield reducing whereas in the tight matching Netherlands is the only country presenting a tiny yield increasing effect. Once again, Italy stands out because of the large value of the CAC, although we also observe a large coefficient for Spain.

\section{Time variation}

Next, we estimate equation (1) at the year/country level. ${ }^{31}$ This we do in order to assess whether, as discussed in Ratha et al. (2018), the findings from papers focused on the early period after implementation of the euro CAC could reflect also transitory effects. By measuring the extent to which the effects have changed since the inception of the CACs our analysis also allows us to understand whether one needs to wait until the dust settles to be able to measure the long-run effect of a deep reform in sovereign bond markets.

Table 5 and 6 presents the results. In both the loose and the tight matching, all countries in the sample show a decrease in yields of CAC bonds especially in the first years after the mandatory introduction of CAC provisions. Looking at the loose matching, the effect seems to stabilize in the territory of lower yields for CAC bonds (Belgium, Finland, France, Italy and Spain) or to converge toward zero over time (Germany and Netherlands). Results are broadly similar when considering the tight matching. Germany and Netherlands represent the only difference that shows slightly larger yields for CAC bonds in 2018. Figure 4 and 5 show some comparison effects respectively for the loose and the tight matching. Netherlands shows a convergence toward a zero difference between CAC and non-CAC bonds yields (Figure 4). Interestingly, Italy shows a sustained reduction in yields coming from the introduction of CACs of around ten basis points. The difference is even larger when looking at the tight matching where yield differential for Italian CAC-bonds stabilize above 10 bps. The comparison between Spain and Germany shows a similar path. German CAC-bonds converge toward a zero difference with no-CAC bonds whereas Spanish CAC-bonds seem to stabilize at a lower yield of around 5 bps. The paths are broadly unchanged when looking at the tight matching.

Following the arguments put forward in Carletti et al. (2018), in both cases there is scope to argue that the inclusion of the CACs led investors to feel an increased degree of protection against the risk of redenomination. There is indeed empirical evidence that financial markets actually priced in the possibility of these countries to convert their domestic law debt in another currency (see Borri (forthcoming) and De Santis (2015)). ${ }^{32}$ More specifically for Italy, two indicators were signalling a high redenomination risk perceived: the ISDA basis and the spread between local law bonds and

\footnotetext{
${ }^{30}$ Austria is dropped because of the low number of observations.

31 In this way, we allow for all of the explanatory variables to have time-varying effects. We also estimated time-varying CAC effects using the following country-specific model: $y_{i, t}=\alpha+\sum_{\forall j \in\{2013,2018\}} \beta_{c j} \cdot \operatorname{CAC}_{i}{ }^{j}+\gamma \cdot \operatorname{Controls}_{i, t}+\chi_{j}+\phi_{t}+\varepsilon_{i, t}$, where the set of $\beta_{c j}$ collects the time-varying effects coming from CACs on country c yields. Results were similar.

32 Borri (forthcoming) shows that after the OMT, the only countries vulnerable to redenomination risk are Italy and Spain. Also De Santis (2015) shows that Italy and Spain were the countries most affected.
} 
foreign law bonds with CACs (see Minenna (2018) and Scaggs (2018)). ${ }^{33}$ With the introduction of CACs in domestic law bonds, this possibility to convert domestic law debt was significantly reduced since it would have exposed the country to a non-negligible litigation risk. This, in line with our results, produced a significant drop in bond yields.

Another possible explanation for these significant results in Italy and Spain relate to the extent to which CACs interfere with the room of manoeuvre that the domestic legal character of the bonds provides. In the Italian case the effect may come from the fact that the inclusion of euro CACs arguably limits the ability of the Italian authorities to use the option of unilaterally extending the maturities of pre-2013 Italian local-law bonds - although the ability of the Italian government to uncontestably apply this option is not guaranteed (Edelen et al., 2012)..$^{34}$ In the case of Spain, the introduction of CACs came at a similar time as a modification in the Spanish constitution to grant the payment of public debt priority over any other budget item (Sanchez-Barrilao, 2013). ${ }^{35}$ The large effect (five bps) that we find for Spain may be driven by such renewed constitutional protection. ${ }^{36}$

\section{A look at the frontline: Single-limb CACs in Swedish foreign law bonds}

The Executive Board of the IMF endorsed the ICMA CAC proposal in October 2014. Since then it has been used in approximately $85 \%$ of foreign-law sovereign bonds issued. According to IMF (2017b), among EU (non-euro area) member states, Bulgaria, Croatia, Romania, and Sweden have adopted the single-limb model in all non-domestic law issuances made by since October, 2014. It has not yet been adopted in Hungary or Poland. ${ }^{37}$

This section focuses on the Swedish experience. Given that the number of available bonds is rather small, we restrict ourselves to analyze the effect of the clause using panel regression techniques. In order to reduce the incidence of comparing bonds that are not that similar, we enlarge the set of explanatory variables to include other characteristics of the bonds such as their coupon and original maturities. An additional complication in this case is that Sweden issues its foreign bonds in both euro and dollar. We estimate effects separately in each of these markets. ${ }^{38}$

\section{Data and Methodology}

\footnotetext{
${ }^{33}$ The ISDA basis refers to difference of the sovereign CDS price computed according to the ISDA 2014 standard (that includes currency conversion as credit event) and the price computed according to the ISDA 2003 standard (that does not include this possibility). In the first half of 2018, the ISDA basis increased from 27.5 to $115 \mathrm{bp}$. The spread between local law bonds and foreign law bonds with CACs indicates the risk underlying local law bonds without CACs and it reached a peak of 26bp between May and June 2018.

${ }^{34}$ The use of this maturity extension might be costly for the government since it might trigger sovereign credit default swaps and lose the eligibility for ECB purchases. Additionally, as the proportion of Italian debt including CACs increases, the potential advantage provided to the Italian government by this clause is being diluted.

${ }^{35}$ This constitutional change was part of the measures adopted in order to regain confidence from investors.

${ }^{36}$ One reason why increased creditor protection should affect more bonds with CACs is presented in Bolton and Jeanne (2009), who shows that "easier-to-restructure" liabilities are more likely to be involved in a partial default. Then, reforms that make partial default less likely should affect junior debt more, which in the Spanish case were the bonds with CACs.

${ }^{37}$ Denmark has issued no foreign law governed debt since October 2014.

${ }^{38}$ Currency-specific effects of CACs are discussed also in Eichengreen and Mody (2003).
} 
We collect all active and matured foreign currency bonds issued by the Swedish government since 2010 from Bloomberg, which gives us 38 eligible bonds. We also retrieve the governing law from Bloomberg, supplementing with data from Dealogic database and International Monetary Fund (2017). From the documents of the Swedish National Debt Office, we found that bonds issued under the Euro Medium Term Note Programme (EMTN), after December 2016, contain the single-limb clause. In order to identify these bonds, we cross-checked information about governing law. Also, from the documents of the Swedish National Debt Office, we know that only bonds included in the EMTN or in the Euro-Commercial Paper (ECP) programmes are issued under English law and that bonds in the ECP programme have maturity lower than one year. Therefore, from the pool of bonds listed in the Swedish National Debt Office's website, we were able to identify six single-limb bonds. Our sample is then made of 6 single-limb bonds, 13 traditional CAC bonds and 4 non-CAC bonds. Details on each of these bonds are presented in Table 3 in the appendix. In terms on methodology, we use the same approach that we have used for the previous section using robust standard errors:

$$
y_{i, t}=\alpha+\beta \cdot C A C_{i}+\beta_{1} \cdot C A C_{i}^{\text {single }}+\gamma \cdot \text { Controls }_{i, t}+\theta_{c}+\psi_{i}+\phi_{t}+\varepsilon_{i, t}
$$

where $y_{i, t}$ is the yield of bond $\mathrm{i}$ at time t. $C A C_{i}$ is a dummy variable that equals 1 for bonds including CACs and 0 otherwise. $C A C_{i}^{\text {single }}$ is a dummy variable that equals to 1 for bonds including enhanced CACs and 0 otherwise. Controls $_{i, t}$ is a vector of control variables including: duration, liquidity, total assets of the Central Bank in percentage of GDP, stock market index, US policy rate and the original maturity and coupon of the bond. $\psi_{i}$ collects bond fixed-effect, $\phi_{t}$ contains time fixed-effects. Since in the sample we have bonds denominated in euro and dollar, we add $\theta_{c}$ as US dollar bond dummy.

We run the same regression considering two samples: 1) post-2009 and 2) post-2013. The first choice is motivated by the fact that until 2009 Sweden had not issued euro-denominated bond for a decade. The second choice relates to the date on which ICMA introduced its enhanced CACs.

Since in these specifications we are forcing a homogeneous relation between CACs and yield in both markets, we run a similar experiment allowing effects to be different according to currency of denomination of the bonds included in the analysis. More specifically, the equation will be:

$$
y_{i, t}=\alpha+\sum_{\forall i \in(\text { euro,dollar })} \beta_{i} \cdot C A C_{i}+\sum_{\forall i \in(\text { euro,dollar })} \beta_{1 i} \cdot C C_{i}^{\text {single }}+\gamma \cdot \text { Controls }_{i, t}+\psi_{i}+\phi_{t}+\varepsilon_{i, t}
$$

Table 7 shows the results for the post 2009 sample and Table 8 for the post 2013. Column 2 represents our baseline specification with weekly fixed effects and bond fixed effects. Yields increase with duration and are larger for dollar-denominated bonds. Bid-ask spread shows instead a negative coefficient. Regarding our variables of interest, we see that traditional CACs provisions imply significant and slightly larger bond yields, between one and two basis points depending on the sample period and the currency of issuance. ${ }^{39}$ Instead, ICMA CACs seem to reduce sovereign yields by between two and four basis points (depending on the sample).

Columns 3 to 5 in both tables control respectively for weekly-fixed effects (column 3), bond-fixed effects (column 4), and weekly-fixed effects plus random bond effects (column 5). Comfortingly,

\footnotetext{
${ }^{39}$ Issuing under foreign law has traditionally been one of the safest way to lend to sovereigns. The introduction of CACs on foreign law bonds that were supposed to be the hardest to restructure might then come with a price, as CACs reduce the degree of protection of the foreign law.
} 
control variables present the same sign and significance. Interestingly, when looking at the currency separation, we notice some differences between bonds. Traditional CACs deliver higher yields both in euro and in dollar, but the effects seem larger for the dollar market. In turn, ICMA CACs seem to have a consistently significant effect in the euro market. Euro-denominated bonds with ICMA CACS trade at lower yields (between half and one basis point depending on the model). ${ }^{40}$

As last step, in order to look at structural differences across markets, we run the model for each currency separately. Given the low number of observations, we do not include time or bond fixedeffect. Column 6 refers to dollar-denominated bonds whereas column 7 focuses on the euro denominated ones. CAC provisions show a significant and positive effect in term of bond yields for the dollar market. Results are instead mixed for the euro market, as enhanced CACs seem to produce a slight decrease in yield.

\section{Conclusions and implications}

In this paper, we have studied the pricing implications from the introduction of two-limb CACs in euro area sovereign bonds. The narrow existing literature points to a beneficial effect for euro area sovereign yields from introducing CACs. This paper complements this literature by using a sample that covers the entire period since the euro CACs were introduced. Taking advantage of this large dataset, we present both country-specific and time-varying effects. This approach allows us to evaluate the extent to which CACs have heterogeneous effects in different economies (because of differences, for example, in the quality of their domestic legal regimes). It also allows us to test whether the effects obtained in previous studies, focused on the early period after implementation, are to be seen as permanent or transitory effects.

We find that yields for bonds with euro CACs are between six and two basis points lower. Additionally, we document a significant degree of heterogeneity in the response of yields to CACs, both in the cross-section and over time. We document large long-run effects in both Italian and Spanish bond markets, while we observe no beneficial effect for Germany and Netherlands. Our results can be interpreted as implying that CACs helped mitigating redenomination fears, but also that they interplay with domestic legal systems that were considered weaker, reassuring investors and reducing the cost of issuing under domestic-law (Carletti et al, 2018). Interestingly, our results also show that in the early years since the implementation of the CACs, it was Netherlands and Germany who seem to have benefited from the inclusion of CACs. We read these dynamics as showing that transitory effects were important during the first years after the CACs were introduced. More generally, we see these results as indication that one needs to wait until the dust settles before being able to measure the long-run effect of deep reforms in sovereign bond markets.

Our paper also tries to contribute the current debate regarding the introduction of a single limb clause in euro area bonds, by presenting preliminary evidence on the effect of ICMA CACs on Swedish sovereign bond yields. Our results show that traditional CACs increase yields, while singlelimb CACs in euro-denominated bonds lower them. Given the low number of bonds and short time series, caution is necessary in drawing conclusions from these results.

\footnotetext{
40 This differential effect could be the result of differences in the investor base of dollar- and euro- denominated bonds (anecdotally, we have heard that dollar Swedish bonds are held by Asian institutions as part of their safe asset portfolios).
} 



\section{References}

Aguiar, M. and M. Amador (2014). Sovereign Debt, Handbook of International Economics, Vol. 4. North-Holland.

Andritzky, J., Christofzik, D. I., Feld, L. P. and Scheuering, U. (2018). A mechanism to regulate sovereign debt restructuring in the euro area, Freiburger Diskussionspapiere zur Ordnungsökonomik, No. 18/01, Walter Eucken Institut, Freiburg i. Br.

Bardozzetti, A. and D. Dottori (2014). Collective action clauses: How do they affect sovereign bond yields? Journal of International Economics 92(2), 286-303.

Becker, T., A. Rochards, and Y. Thaicharoen (2003). Bond restructuring and moral hazard: are collective action clauses costly? Journal of International Economics 61(1), 127-161.

Bolton, P. and O. Jeanne (2009). Structuring and restructuring sovereign debt: The role of seniority. The Review of Economic Studies 76(3), 879-902.

Borri, N. (forthcoming). Redenomination-Risk Spillovers in the Eurozone, Economics Letters.

Bradley, M. and M. Gulati (2013). Collective action clauses for the eurozone. Review of Finance 18(6), 2045-2102.

Buchheit, L. C., Gulati, M. and Tirado, I. (2013). The Problem of Holdout Creditors in Eurozone Sovereign Debt Restructurings, Mimeo.

Cannata, M. (2018). Nuove clausole per le crisi del debito: rischio circolo vizioso. LaVoce.

Carletti, E., P. Colla, M. Gulati, and S. Ongena (2018). The price of law: The case of the Eurozone collective action clauses. Mimeo.

Carletti, E., P. Colla, M. Gulati, and S. Ongena (2018). Pricing contract terms in a crisis: Venezuelan bonds in 2016, Capital Markets Law Journal, Vol. 11(4), pp. 540-555.

Choi, S., M. Gulati, and E. Scott (2018). Hidden holdouts: Contract arbitrageurs and the pricing of collective rights. Columbia Law and Economics Working Paper 586.

De Santis, R. (2017). Sovereign spreads in the eurozone on the rise: Redenomination risk versus political risk. VoxEU .

De Santis, R. (2015). A measure of redenomination risk, ECB Working Paper Series 1785.

Edelen, A., P. Gentry, J. Landfried, and T. Monteleone (2012). A mature approach: Using a unilateral or voluntary extension of maturities to restructure italian debt. Mimeo.

Eichengreen, B. and A. Mody (2003). Is aggregation a problem for sovereign debt restructuring? American Economic Review 93(2), 80-84.

Eichengreen, B. and A. Mody (2004). Do collective action clauses raise borrowing costs? Economic Journal 114(495), 247-264. 
Eichengreen, B. and R. Portes (1995). Crisis? What Crisis? Orderly Workouts for Sovereign Debtors. London: Centre for Economic Policy Research.

Feldman, T., A. Jung, and J. Klein (2015). Buy and hold versus timing strategies: The winner is... The Journal of Portfolio Management 42(1), 110-118.

Fang, C. (2015). Cost and efficacy of collective action clauses, Unpublished manuscript.

Gelpern, A., B. Heller, and B. Setser (2015). Count the Limbs: Designing Robust Aggregation Clauses in Sovereign Bonds. Georgetown University Law Center.

Ghosal, S. and K. Thampanishvong (2013). Does strengthening collective action clauses (cacs) help? Journal of International Economics 89(1), 68-78.

Haldane, A., A. Penalver, V. Saporta, and H. S. Shin (2005). Analytics of sovereign debt restructuring. Journal of International Economics 65(2), 315-333.

Ho, D. E., Kosuke I., King G. and E. Stuart, (2007). Matching as nonparametric preprocessing for reducing model dependence in parametric causal inference. Political Analysis 15(3), 199-236.

House, B., M. Joy, and N. Sobrinho (2017). Sovereign debt restructurings: The costs of delay. Mimeo. International Monetary Fund (2017). Second Progress Report on Inclusion of Enhanced Contractual Provisions in International Sovereign Bond Contracts.

Krueger, A. (2002). A New Approach to Sovereign Debt Restructuring. Nordea (2016). ECB preview bond scarcity is not the only challenge. Nordea Research.

Minenna, M. (2018). Risk segregation and market fragility in the Eurozone, Financial Times Alphaville, June.

Pitchford, R. and M. Wright (2012). Holdouts in sovereign debt restructuring: A theory of negotiation in a weak contractual environment. Review of Economic Studies, Volume 79, Number 2, 812-837.

Ratha, D., S. De, and S. Kurlat (2018). Does governing law affect bond spreads? Emerging Markets Review 36, 60-78.

Richards, A. and M. Giugiatti (2003). Do collective action clauses influence bond yields? New evidence from emerging markets. International Finance 6(3), 415-447.

Sanchez-Barrilao, J. (2013). The sovereign debt crisis and the reform of article 135 of the Spanish constitution. Boletín Mexicano de Derecho Comparado 46 (137).

Scaggs, A. (2018). Italian markets: Redistribution risk revives "redenomination risk", Financial Times Alphaville, May.

Schumacher, J., Chamon, M. and Trebesch, C. (forthcoming). Foreign Law Bonds: Can They Reduce Sovereign Borrowing Costs?, Journal of International Economics.

Schumacher, J., Trebesch, C. and Enderlein, H. (2018). Sovereign Defaults in Court, ECB Working Paper Series No 2135. 
Scott, R. E., Gulati, M. and Choi, J. (2018). Hidden Holdouts: Contract Arbitrageurs and the Pricing of Collective Rights, Law \& Economics Research paper series No. 18-27

Shleifer, A. (2003). Will the sovereign debt market survive? American Economic Review 93(2), 85-90.

Steffen, C. G. and J. Schumacher (2014). Debt restructuring in the euro area: How can sovereign debt be restructured more effectively? DIW Economic Bulletin 4(10), 19-27.

Taylor, J. (2002). Sovereign debt restructuring: a US perspective. Washington D.C.: Department of the Treasury (April).

Tsatsaronis, K. (1999). The effect of collective action clauses on sovereign bond yield. BIS Quarterly Review: International Banking and Financial Market Developments, 22-23.

Zandstra, D. (2017). New aggregated collective action clauses and evolution in the restructuring of sovereign debt securities. Capital Markets Law Journal 12(2).

Zettelmeyer, J. (2018). Managing deep debt crises in the euro area: Towards a feasible regime. Global Policy 9(1), 70-79. 


\section{Appendix}

Table 2: Country breakdown of matched CAC and no-CAC bonds

\begin{tabular}{lcccc}
\multicolumn{5}{c}{ Country breakdown during data preparations } \\
\hline \hline Issuer & $\begin{array}{c}\text { All bonds with } \\
\text { CAC provisions }\end{array}$ & $\begin{array}{c}\text { Usable bonds with } \\
\text { CAC provisions }\end{array}$ & $\begin{array}{c}\text { CAC \& No-CAC matched pair } \\
\text { (loose matching) }\end{array}$ & $\begin{array}{c}\text { CAC \& No-CAC matched pair } \\
\text { (tight matching) }\end{array}$ \\
\hline Austria & 19 & 13 & 11 & 6 \\
Belgium & 23 & 21 & 15 & 5 \\
Finland & 12 & 12 & 10 & 8 \\
France & 34 & 27 & 24 & 12 \\
Germany & 53 & 44 & 43 & 28 \\
Ireland & 14 & 10 & 5 & 1 \\
Italy & 80 & 59 & 53 & 30 \\
Netherlands & 16 & 8 & 8 & 6 \\
Portugal & 11 & 9 & 5 & 1 \\
Spain & 35 & 32 & 27 & 115 \\
\hline Total & 297 & 235 & 201 & 18 \\
\hline
\end{tabular}

Note: The above table describes the evolution of country breakdown during data preparations. We perform the initial filtering using Bloomberg to retrieve the fixed or zero coupon euro-denominated medium- and long-term sovereign bonds issued by euro area governments between the introduction of Euro-CAC and 5th Sep. 2018. All filtered bonds from Bloomberg have CAC as a contractual provision. We further narrow down to the bonds with domestic law as flagged either by Bloomberg or Dealogic. In the last two columns, we show the number of pairs we form by matching the residual maturity of CAC and No-CAC bonds with two different limits.

Table 3:

Sweden - Bonds included in the sample

\begin{tabular}{|c|c|c|c|c|}
\hline \multicolumn{5}{|c|}{ CAC - single limb } \\
\hline ISIN & Issue date & Maturity date & Amount (bn) & Coupon \\
\hline US87020DBE31 & $15 / 02 / 2018$ & $15 / 02 / 2021$ & 3 & 2.375 \\
\hline XS1756338551 & $24 / 01 / 2018$ & $24 / 04 / 2023$ & 4.95664 & 0.125 \\
\hline US87020DBC74 & $11 / 01 / 2018$ & $15 / 02 / 2023$ & 3 & 2.375 \\
\hline US87020DBB91 & $02 / 11 / 2017$ & $02 / 11 / 2020$ & 2.5 & 1.875 \\
\hline US87020DBA19 & $25 / 07 / 2017$ & $25 / 07 / 2019$ & 2.75 & 1.5 \\
\hline US87020DAZ78 & $06 / 04 / 2017$ & $06 / 04 / 2020$ & 2 & 1.625 \\
\hline \multicolumn{5}{|c|}{ CAC - traditional } \\
\hline ISIN & Issue date & Maturity date & Amount (bn) & Coupon \\
\hline US87020DAY04 & $21 / 10 / 2016$ & $21 / 10 / 2019$ & 3 & 1.125 \\
\hline US87020DAW48 & $15 / 03 / 2016$ & $15 / 03 / 2019$ & 2 & 1.125 \\
\hline US87020DAV64 & $05 / 10 / 2015$ & 05/10/2018 & 1 & 1 \\
\hline US87020DAU81 & $13 / 05 / 2015$ & $15 / 05 / 2018$ & 2.25 & 1.125 \\
\hline US87020DAT19 & $24 / 03 / 2015$ & $24 / 03 / 2020$ & 2 & 1.625 \\
\hline US87020DAS36 & $16 / 03 / 2015$ & $16 / 03 / 2017$ & 1.5 & 0.75 \\
\hline XS1189262345 & $12 / 02 / 2015$ & $12 / 02 / 2020$ & 1.708155 & 0.05 \\
\hline US87020DAR52 & $23 / 01 / 2015$ & $23 / 01 / 2018$ & 2.5 & 0.875 \\
\hline US87020DAQ79 & $13 / 11 / 2014$ & $13 / 11 / 2017$ & 3 & 1 \\
\hline US87020DAP96 & $19 / 09 / 2014$ & $19 / 09 / 2016$ & 2 & 0.625 \\
\hline XS1081254465 & $25 / 06 / 2014$ & $25 / 06 / 2017$ & 0.68191 & 0.13 \\
\hline XS0882814386 & $31 / 01 / 2013$ & $31 / 01 / 2018$ & 5.4338 & 0.875 \\
\hline XS0670833853 & $02 / 09 / 2011$ & $02 / 09 / 2013$ & 1.4203 & 0.875 \\
\hline \multicolumn{5}{|l|}{ no CAC } \\
\hline ISIN & Issue date & Maturity date & Amount (bn) & Coupon \\
\hline XS1062909384 & $02 / 05 / 2014$ & 02/05/2019 & 3.119355 & 0.75 \\
\hline XS0997474639 & $27 / 11 / 2013$ & $27 / 11 / 2016$ & 1.35703 & 0.25 \\
\hline US87020DAG97 & $28 / 03 / 2013$ & 29/03/2016 & 1 & 0.375 \\
\hline US87020DAA28 & $03 / 06 / 2011$ & 03/06/2014 & 1.5 & 1 \\
\hline
\end{tabular}



Figure 1: Assessing the quality of the match between CACs and no-CACs bonds: Original maturities

Full loose sample

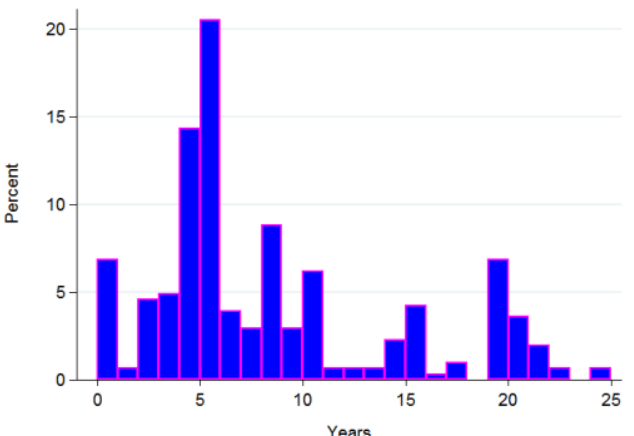

Pre-2015 loose sample

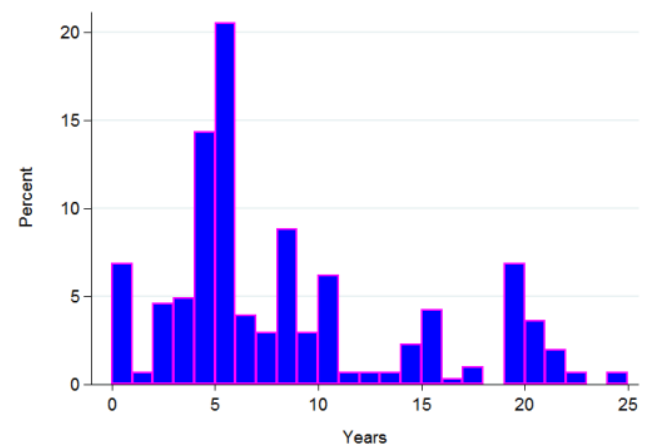

Figure 2: Assessing the quality of the match between CACs and no-CACs bonds: Coupons

Full loose sample

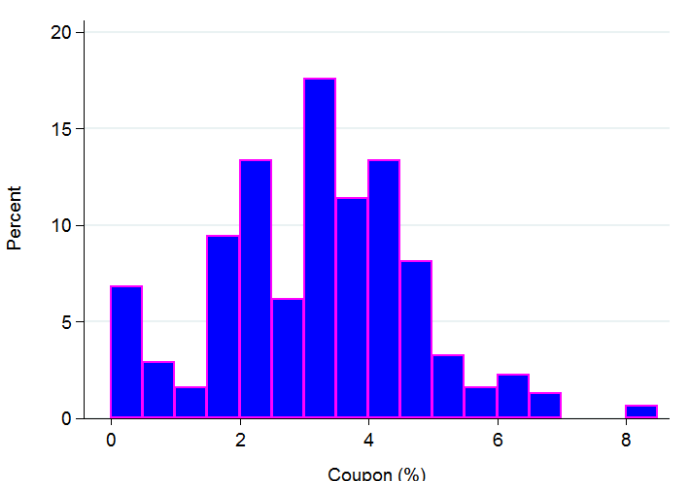

Pre-2015 loose sample

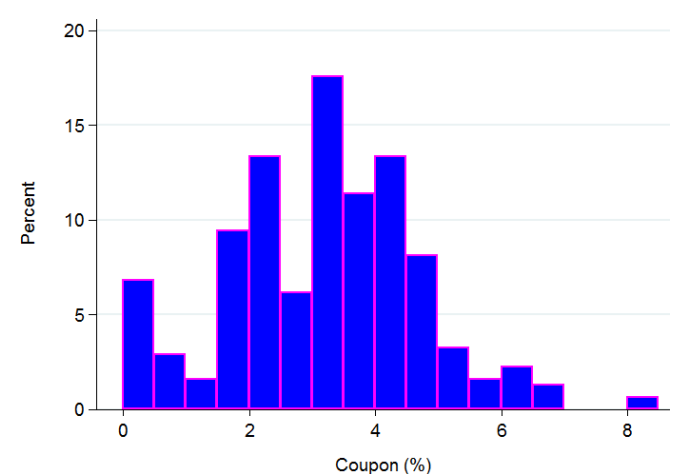


List of variables included in the analysis

\begin{tabular}{|c|c|}
\hline Variable & Sources \\
\hline CAC provisions & Bloomberg \\
\hline Weekly secondary market yield (in bps) & Bloomberg \\
\hline Duration & Bloomberg \\
\hline Bid-ask spread & Bloomberg \\
\hline Rating converted into a numeric scale (1-21) where 21 represents AAA & Bloomberg \\
\hline Euro area 10 -year government bond yield & Bloomberg \\
\hline Total government debt securities & ECB \\
\hline $\begin{array}{l}\text { Net purchases of debt securities under the PSPP (Public Sector Purchase Programme) } \\
\qquad \text { in \% of total goverement debt securities }\end{array}$ & Haver Analytics \\
\hline $\begin{array}{l}\text { Holdings of debt securities under the PSPP (Public Sector Purchase Programme) in \% } \\
\text { of total goverement debt securities }\end{array}$ & Haver Analytics \\
\hline US policy rate & Haver Analytics \\
\hline Swedish Central Bank total assets in \% of GDP & Haver Analytics \\
\hline Swedish stock market index & Haver Analytics \\
\hline
\end{tabular}


Table 4: Euro-CACs and sovereign yields

\begin{tabular}{|c|c|c|c|c|c|c|c|}
\hline & Carletti et a. (2018) & Carletti et a. (2018) & Loose matching & Loose matching & Tight matching & Tight matching & $\begin{array}{l}\text { Tight matching - } \\
\text { Italy excluded }\end{array}$ \\
\hline Euro area reference yield & $\begin{array}{l}1.008 * * * \\
(145.66)\end{array}$ & $\begin{array}{c}1.008^{* * *} \\
(25.24)\end{array}$ & $\begin{array}{c}1.154^{* * *} \\
(22.42)\end{array}$ & $\begin{array}{c}1.257^{* * *} \\
(24.20)\end{array}$ & $\begin{array}{c}1.082^{* * *} \\
(15.05)\end{array}$ & $\begin{array}{c}1.243^{* * *} \\
(17.35)\end{array}$ & $\begin{array}{c}1.283^{* * *} \\
(22.07)\end{array}$ \\
\hline Credit rating & $\begin{array}{l}-27.10 * * * \\
(-210.52)\end{array}$ & $\begin{array}{c}-17.07^{* * *} \\
(-13.76)\end{array}$ & $\begin{array}{c}-20.42 * * * \\
(-305.69)\end{array}$ & $\begin{array}{c}-19.34^{* * *} \\
(-35.99)\end{array}$ & $\begin{array}{c}-18.50 * * * \\
(-214.91)\end{array}$ & $\begin{array}{c}-19.99 * * * \\
(-25.10)\end{array}$ & $\begin{array}{c}-45.42^{* * *} \\
(-57.32)\end{array}$ \\
\hline Central bank bond holdings & - & - & $\begin{array}{c}1.291^{* * *} \\
(14.76)\end{array}$ & $\begin{array}{c}1.812^{* * *} \\
(20.23)\end{array}$ & $\begin{array}{c}1.184 * * * \\
(11.75)\end{array}$ & $\begin{array}{c}2.055^{* * *} \\
(19.32)\end{array}$ & $\begin{array}{c}2.810^{* * *} \\
(36.93)\end{array}$ \\
\hline Central bank flow purchases & - & - & $\begin{array}{c}50.78^{* * *} \\
(22.72)\end{array}$ & $\begin{array}{c}72.82^{* * *} \\
(29.44)\end{array}$ & $\begin{array}{c}86.53^{* * *} \\
(32.95)\end{array}$ & $\begin{array}{c}122.4^{* * *} \\
(37.30)\end{array}$ & $\begin{array}{c}25.81^{* * *} \\
(9.58)\end{array}$ \\
\hline Bond duration & $\begin{array}{l}14.80 * * * \\
(103.70)\end{array}$ & $\begin{array}{c}14.40 * * * \\
(102.37)\end{array}$ & $\begin{array}{c}14.96^{* * *} \\
(222.90)\end{array}$ & $\begin{array}{c}14.68^{* * *} \\
(215.69)\end{array}$ & $\begin{array}{c}18.37^{* * *} \\
(174.14)\end{array}$ & $\begin{array}{c}18.50 * * * \\
(160.54)\end{array}$ & $\begin{array}{l}15.76^{* * *} \\
(193.10)\end{array}$ \\
\hline Bond bid-ask & $\begin{array}{c}-1.621^{* * *} \\
(-6.01)\end{array}$ & $\begin{array}{c}-2.146^{* * *} \\
(-8.16)\end{array}$ & $\begin{array}{c}0.354^{* * *} \\
(4.40)\end{array}$ & $\begin{array}{c}0.132^{*} \\
(1.70)\end{array}$ & $\begin{array}{c}0.444^{* * *} \\
(5.64)\end{array}$ & $\begin{array}{c}0.306^{* * *} \\
(3.93)\end{array}$ & $\begin{array}{c}0.270^{* * *} \\
(3.58)\end{array}$ \\
\hline Collective action clause dummy & $\begin{array}{c}-10.83^{* * *} \\
(-10.86) \\
\end{array}$ & $\begin{array}{c}-6.410^{* * *} \\
(-7.03) \\
\end{array}$ & $\begin{array}{c}-5.300 * * * \\
(-14.07) \\
\end{array}$ & $\begin{array}{c}-4.450 * * * \\
(-12.22) \\
\end{array}$ & $\begin{array}{c}-3.725 * * * \\
(-8.24) \\
\end{array}$ & $\begin{array}{c}-4.141^{* * *} \\
(-9.93) \\
\end{array}$ & $\begin{array}{c}-2.257^{* * *} \\
(-6.51) \\
\end{array}$ \\
\hline $\begin{array}{l}\text { Country fixed effect } \\
\text { Weekly fixed effects }\end{array}$ & $\begin{array}{l}\mathrm{N} \\
\mathrm{N}\end{array}$ & $\begin{array}{l}Y \\
Y\end{array}$ & $\begin{array}{l}N \\
Y\end{array}$ & $\begin{array}{l}Y \\
Y\end{array}$ & $\begin{array}{l}\mathrm{N} \\
\mathrm{Y}\end{array}$ & $\begin{array}{l}Y \\
Y\end{array}$ & $\begin{array}{l}Y \\
Y\end{array}$ \\
\hline Numer of observations & 12920 & 12920 & 55064 & 55064 & 30683 & 30683 & 22866 \\
\hline R-squared & 0.889 & 0.906 & 0.892 & 0.899 & 0.897 & 0.907 & 0.939 \\
\hline
\end{tabular}

t statistics in parentheses. ${ }^{*} p<0.10,{ }^{* *} p<0.05,{ }^{* * *} p<0.01$ 
Figure 3: Country-specific effects

Loose matching

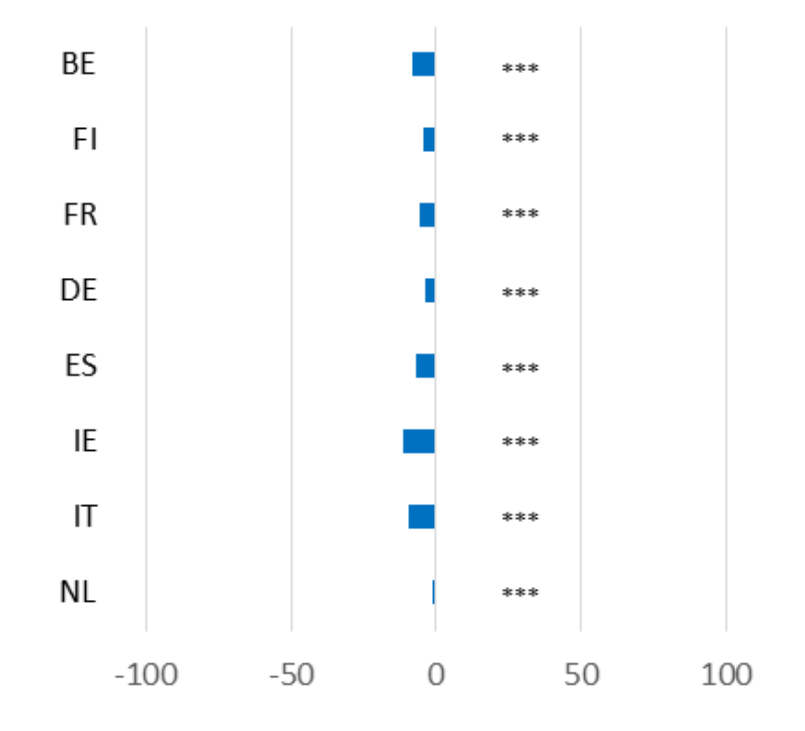

Tight matching

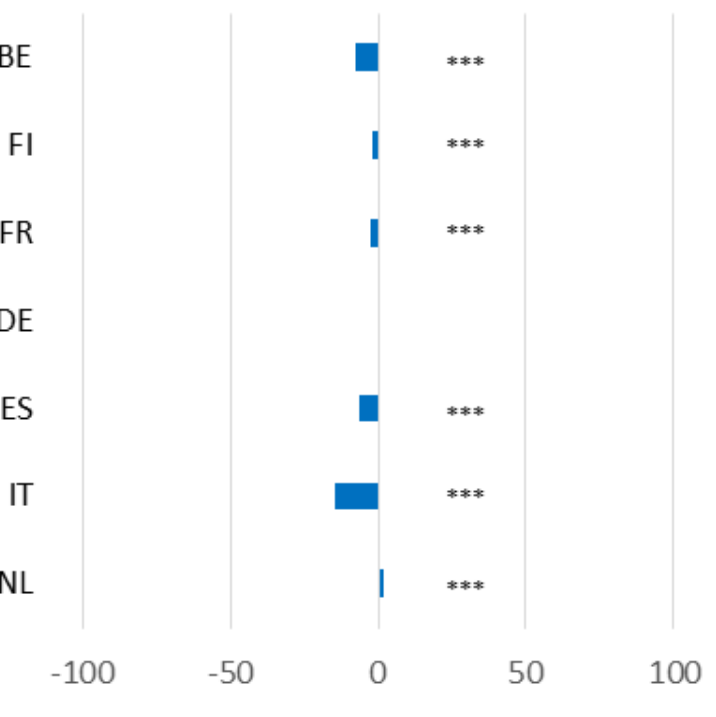

Note: These figures plot the coefficient corresponding to the CAC variable for each of the country-specific regressions. 
Table 5: Country-specific time varying effect

\begin{tabular}{|c|c|c|c|c|c|c|}
\hline & \multicolumn{6}{|c|}{ Loose matching } \\
\hline & 2013 & 2014 & 2015 & 2016 & 2017 & 2018 \\
\hline Belgium & $\begin{array}{c}-4.987 * * * \\
(-3.55)\end{array}$ & $\begin{array}{c}-8.384 * * * \\
(-7.29)\end{array}$ & $\begin{array}{c}-6.882 * * * \\
(-6.77)\end{array}$ & $\begin{array}{c}-8.819 * * * \\
(-10.35)\end{array}$ & $\begin{array}{c}-8.738 * * * \\
(-11.13)\end{array}$ & $\begin{array}{c}-6.427^{* * *} \\
(-7.13)\end{array}$ \\
\hline Finland & $\begin{array}{c}4.994 * * * \\
(6.25)\end{array}$ & $\begin{array}{l}-0.612 \\
(-0.79)\end{array}$ & $\begin{array}{c}-5.194 * * * \\
(-4.92)\end{array}$ & $\begin{array}{c}-3.586 * * * \\
(-4.74)\end{array}$ & $\begin{array}{c}-4.119 * * * \\
(-8.60)\end{array}$ & $\begin{array}{c}-4.127 * * * \\
(-6.06)\end{array}$ \\
\hline France & $\begin{array}{c}-5.545^{*} \\
(-1.72)\end{array}$ & $\begin{array}{c}-5.563 * * * \\
(-5.15)\end{array}$ & $\begin{array}{c}-4.345^{* * *} \\
(-6.19)\end{array}$ & $\begin{array}{c}-5.500 * * * \\
(-9.29)\end{array}$ & $\begin{array}{c}-6.891^{* * *} \\
(-10.33)\end{array}$ & $\begin{array}{c}-4.107^{* * *} \\
(-6.00)\end{array}$ \\
\hline Germany & $\begin{array}{c}-4.921^{* *} \\
(-2.00)\end{array}$ & $\begin{array}{c}-7.508 * * * \\
(-5.66)\end{array}$ & $\begin{array}{c}-2.766 * * * \\
(-3.70)\end{array}$ & $\begin{array}{c}-1.496 * * * \\
(-2.77)\end{array}$ & $\begin{array}{c}-2.036 * * * \\
(-3.08)\end{array}$ & $\begin{array}{c}0.0657 \\
(0.07)\end{array}$ \\
\hline Italy & $\begin{array}{c}-5.476^{* *} \\
(-2.25)\end{array}$ & $\begin{array}{c}-16.82^{* * *} \\
(-9.38)\end{array}$ & $\begin{array}{c}-8.705^{* * *} \\
(-7.68)\end{array}$ & $\begin{array}{c}-9.100 * * * \\
(-10.52)\end{array}$ & $\begin{array}{c}-7.203^{* * *} \\
(-6.00)\end{array}$ & $\begin{array}{c}-6.877^{* * *} \\
(-3.99)\end{array}$ \\
\hline Netherlands & $\begin{array}{c}-14.48 * * * \\
(-13.28)\end{array}$ & $\begin{array}{c}-2.175^{* *} \\
(-1.98)\end{array}$ & $\begin{array}{l}-0.711 \\
(-0.68)\end{array}$ & $\begin{array}{c}2.897^{* * *} \\
(2.97)\end{array}$ & $\begin{array}{c}1.855^{*} \\
(1.68)\end{array}$ & $\begin{array}{l}1.212 \\
(1.31)\end{array}$ \\
\hline Spain & $\begin{array}{l}0.412 \\
(0.17)\end{array}$ & $\begin{array}{c}-2.760 * * \\
(-2.48)\end{array}$ & $\begin{array}{c}-9.116 * * * \\
(-9.06)\end{array}$ & $\begin{array}{c}-6.803^{* * *} \\
(-9.49)\end{array}$ & $\begin{array}{c}-8.359 * * * \\
(-11.80)\end{array}$ & $\begin{array}{c}-6.239 * * * \\
(-9.18)\end{array}$ \\
\hline All countries & $\begin{array}{c}-4.220 * * * \\
(-3.37)\end{array}$ & $\begin{array}{c}-7.978 * * * \\
(-9.76)\end{array}$ & $\begin{array}{c}-4.740 * * * \\
(-8.32)\end{array}$ & $\begin{array}{c}-4.498 * * * \\
(-8.59)\end{array}$ & $\begin{array}{c}-3.852 * * * \\
(-6.13)\end{array}$ & $\begin{array}{c}-2.008 * * \\
(-2.25)\end{array}$ \\
\hline
\end{tabular}

Table 6: Country-specific time varying effect

\begin{tabular}{|c|c|c|c|c|c|c|}
\hline & \multicolumn{6}{|c|}{ Tight matching } \\
\hline & 2013 & 2014 & 2015 & 2016 & 2017 & 2018 \\
\hline Belgium & $\begin{array}{c}-5.135 * * * \\
(-5.38)\end{array}$ & $\begin{array}{c}-7.957 * * * \\
(-7.21)\end{array}$ & $\begin{array}{c}-10.42 * * * \\
(-8.40)\end{array}$ & $\begin{array}{c}-7.825 * * * \\
(-9.11)\end{array}$ & $\begin{array}{c}-6.345 * * * \\
(-7.50)\end{array}$ & $\begin{array}{c}-4.291 * * * \\
(-4.93)\end{array}$ \\
\hline Finland & $\begin{array}{l}-0.180 \\
(-0.22)\end{array}$ & $\begin{array}{c}-3.429 * * * \\
(-3.35)\end{array}$ & $\begin{array}{c}-4.385 * * * \\
(-4.92)\end{array}$ & $\begin{array}{l}-0.849 \\
(-1.18)\end{array}$ & $\begin{array}{c}-1.982 * * * \\
(-5.91)\end{array}$ & $\begin{array}{l}0.521 \\
(1.01)\end{array}$ \\
\hline France & $\begin{array}{c}-12.76 * * * \\
(-3.30)\end{array}$ & $\begin{array}{l}-1.521 \\
(-0.79)\end{array}$ & $\begin{array}{c}-3.893 * * * \\
(-4.78)\end{array}$ & $\begin{array}{c}-1.174^{*} \\
(-1.69)\end{array}$ & $\begin{array}{c}-2.866 * * * \\
(-3.44)\end{array}$ & $\begin{array}{l}-0.558 \\
(-0.64)\end{array}$ \\
\hline Germany & $\begin{array}{c}-5.822 * * * \\
(-15.10)\end{array}$ & $\begin{array}{c}-1.750 * * * \\
(-3.09)\end{array}$ & $\begin{array}{c}-1.891 * * * \\
(-5.99)\end{array}$ & $\begin{array}{l}0.108 \\
(0.37)\end{array}$ & $\begin{array}{c}0.968 * * * \\
(3.27)\end{array}$ & $\begin{array}{c}2.309 * * * \\
(5.68)\end{array}$ \\
\hline Italy & $\begin{array}{l}0.446 \\
(0.35)\end{array}$ & $\begin{array}{c}-15.34 * * * \\
(-13.28)\end{array}$ & $\begin{array}{c}-16.07 * * * \\
(-20.20)\end{array}$ & $\begin{array}{c}-12.88 * * * \\
(-22.43)\end{array}$ & $\begin{array}{c}-14.01 * * * \\
(-25.84)\end{array}$ & $\begin{array}{c}-13.26 * * * \\
(-16.61)\end{array}$ \\
\hline Netherlands & $\begin{array}{c}-10.75 * * * \\
(-15.16)\end{array}$ & $\begin{array}{c}-2.271^{* *} \\
(-2.25)\end{array}$ & $\begin{array}{l}1.249 \\
(1.58)\end{array}$ & $\begin{array}{c}3.818^{* * *} \\
(4.42)\end{array}$ & $\begin{array}{c}4.822 * * * \\
(3.37)\end{array}$ & $\begin{array}{c}4.590 * * * \\
(5.05)\end{array}$ \\
\hline Spain & $\begin{array}{c}5.078 * * \\
(2.20) \\
\end{array}$ & $\begin{array}{c}-3.893 * * * \\
(-3.87) \\
\end{array}$ & $\begin{array}{c}-7.920 * * * \\
(-8.87)\end{array}$ & $\begin{array}{c}-7.791 * * * \\
(-11.12) \\
\end{array}$ & $\begin{array}{c}-7.701 * * * \\
(-10.79)\end{array}$ & $\begin{array}{c}-4.622 * * * \\
(-6.82)\end{array}$ \\
\hline All countries & $\begin{array}{c}-2.460 * * \\
(-2.03)\end{array}$ & $\begin{array}{c}-5.939 * * * \\
(-7.60)\end{array}$ & $\begin{array}{c}-4.721^{* * *} \\
(-8.41)\end{array}$ & $\begin{array}{c}-2.598^{* * *} \\
(-4.85)\end{array}$ & $\begin{array}{c}-2.294 * * * \\
(-3.61)\end{array}$ & $\begin{array}{c}-1.929 * \\
(-1.78)\end{array}$ \\
\hline
\end{tabular}


Figure 4: Country comparison (loose matching)
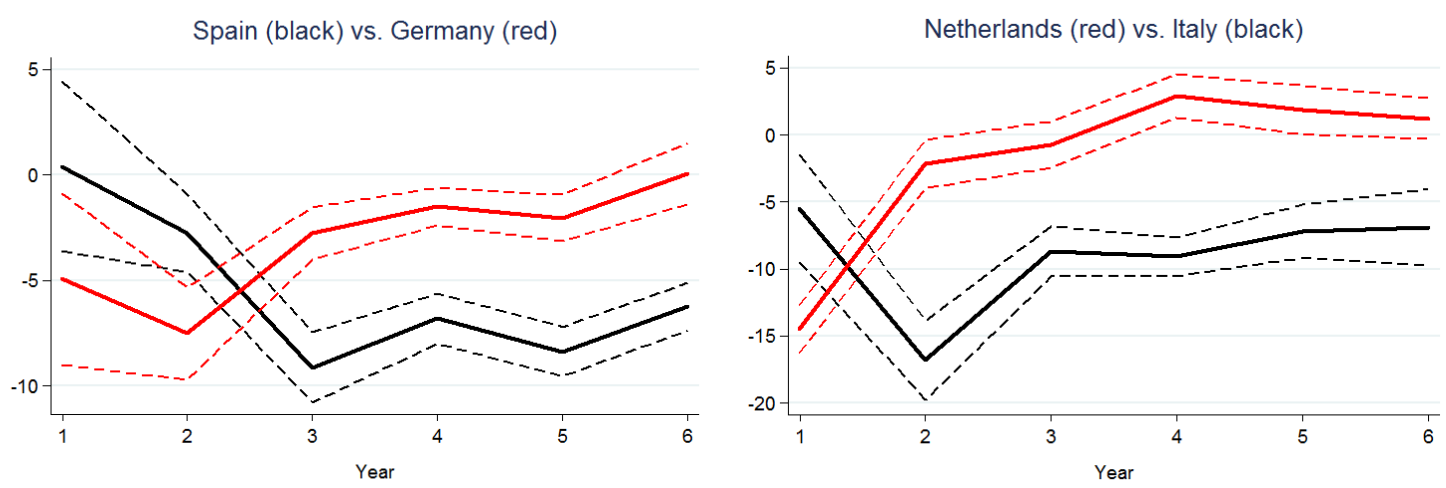

Note: Yield time-varying effect

Figure 5: Country comparison (tight matching)
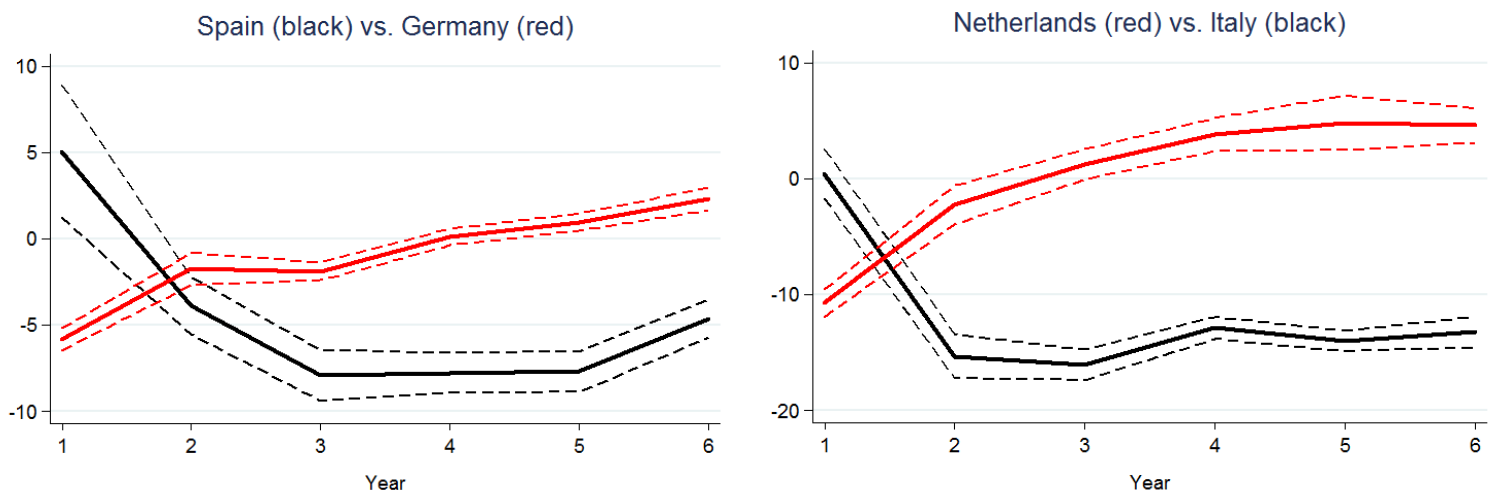

Note: Yield time-varying effect 
Table 7: Traditional vs. Enhanced CACs in Swedish sovereign bonds. Post-2009 sample

\begin{tabular}{|c|c|c|c|c|c|c|c|}
\hline & \multicolumn{7}{|c|}{ Post-2009 sample } \\
\hline & Common effects & Common effects & Currency-specific effects & Currency-specific effects & Currency-specific effects & Only US Dollar & Only Eur \\
\hline Bond duration & $\begin{array}{c}0.359 * * * \\
(34.67)\end{array}$ & $\begin{array}{c}1.061^{* * *} \\
(3.22)\end{array}$ & $\begin{array}{c}0.347^{* * *} \\
(27.82)\end{array}$ & $\begin{array}{c}0.363^{* * *} \\
(16.31)\end{array}$ & $\begin{array}{c}0.347^{* * *} \\
(4.71)\end{array}$ & $\begin{array}{c}0.207^{* * *} \\
(23.84)\end{array}$ & $\begin{array}{c}0.258^{* * *} \\
(15.66)\end{array}$ \\
\hline Bond bid-ask & $\begin{array}{c}-201.0 * * * \\
(-10.16)\end{array}$ & $\begin{array}{c}-329.3 * * * \\
(-15.50)\end{array}$ & $\begin{array}{c}-242.1^{* * *} \\
(-12.67)\end{array}$ & $\begin{array}{c}-204.0^{* * *} \\
(-11.31)\end{array}$ & $\begin{array}{c}-242.1 * * * \\
(-3.16)\end{array}$ & $\begin{array}{l}9.239 \\
(0.61)\end{array}$ & $\begin{array}{c}-58.29 * * * \\
(-3.16)\end{array}$ \\
\hline Central bank size (\% GDP) & $\begin{array}{l}645.2^{*} \\
(1.83)\end{array}$ & $\begin{array}{c}441.7^{*} \\
(1.80)\end{array}$ & $\begin{array}{c}662.1^{* *} \\
(2.10)\end{array}$ & $\begin{array}{c}-0.614^{* * *} \\
(-3.93)\end{array}$ & $\begin{array}{c}662.0^{* *} \\
(2.29)\end{array}$ & $\begin{array}{c}-0.236^{* * *} \\
(-3.01)\end{array}$ & $\begin{array}{c}-0.648^{* * *} \\
(-5.10)\end{array}$ \\
\hline US policy rate & $\begin{array}{c}-11142.4^{*} \\
(-1.82)\end{array}$ & $\begin{array}{c}-7505.4^{*} \\
(-1.76)\end{array}$ & $\begin{array}{c}-11440.6^{* *} \\
(-2.09)\end{array}$ & $\begin{array}{c}85.41^{* * *} \\
(31.19)\end{array}$ & $\begin{array}{c}-11439.8^{* *} \\
(-2.29)\end{array}$ & $\begin{array}{c}98.35 * * * \\
(58.99)\end{array}$ & $\begin{array}{c}15.54^{* * * *} \\
(7.67)\end{array}$ \\
\hline Stock market index & $\begin{array}{l}-0.351^{*} \\
(-1.81)\end{array}$ & $\begin{array}{l}-0.229^{*} \\
(-1.69)\end{array}$ & $\begin{array}{c}-0.361^{* *} \\
(-2.08)\end{array}$ & $\begin{array}{c}-0.000352^{* *} \\
(-2.23)\end{array}$ & $\begin{array}{c}-0.361^{* *} \\
(-2.28)\end{array}$ & $\begin{array}{c}0.000944^{* * *} \\
(7.59)\end{array}$ & $\begin{array}{c}-0.000613^{* * *} \\
(-3.55)\end{array}$ \\
\hline US dollar bond dummy & $\begin{array}{c}0.495 * * * \\
(26.99)\end{array}$ & $\begin{array}{l}0.323 \\
(1.61)\end{array}$ & $\begin{array}{c}0.472^{* * *} \\
(17.25)\end{array}$ & $\begin{array}{c}-0.103^{* * *} \\
(-3.38)\end{array}$ & $\begin{array}{c}0.472^{* *} \\
(2.06)\end{array}$ & & \\
\hline Bond coupon & $\begin{array}{c}0.741^{* * *} \\
(31.64)\end{array}$ & $\begin{array}{c}2.319 * * * \\
(2.83)\end{array}$ & $\begin{array}{c}0.555^{* * *} \\
(17.50)\end{array}$ & $\begin{array}{c}0.705^{* * *} \\
(12.63)\end{array}$ & $\begin{array}{c}0.555^{* * * *} \\
(3.53)\end{array}$ & $\begin{array}{c}0.0781^{* * *} \\
(3.28)\end{array}$ & $\begin{array}{c}0.307^{* * *} \\
(11.72)\end{array}$ \\
\hline Bond original maturity & $\begin{array}{c}-0.359 * * * \\
(-27.36) \\
\end{array}$ & $\begin{array}{c}-1.705 * * * \\
(-2.86) \\
\end{array}$ & $\begin{array}{c}-0.285 * * * \\
(-14.23) \\
\end{array}$ & $\begin{array}{c}-0.527^{* * *} \\
(-14.34) \\
\end{array}$ & $\begin{array}{c}-0.285 * * * \\
(-2.62) \\
\end{array}$ & $\begin{array}{c}-0.00198 \\
(-0.13) \\
\end{array}$ & $\begin{array}{c}-0.199 * * * \\
(-9.35) \\
\end{array}$ \\
\hline Traditional CAC dummy & $\begin{array}{c}0.168^{* * *} \\
(9.86)\end{array}$ & $\begin{array}{c}0.905 * * * \\
(2.99)\end{array}$ & & & & $\begin{array}{c}0.234^{* * *} \\
(9.51)\end{array}$ & $\begin{array}{c}0.0677^{* * *} \\
(5.13)\end{array}$ \\
\hline ICMA CAC dummy & $\begin{array}{c}-0.444^{* * *} \\
(-10.02) \\
\end{array}$ & $\begin{array}{c}-2.214^{* * *} \\
(-3.41) \\
\end{array}$ & & & & $\begin{array}{c}0.202^{* * *} \\
(3.81) \\
\end{array}$ & $\begin{array}{c}-0.121 * * * \\
(-3.13) \\
\end{array}$ \\
\hline Traditional CAC dummy - Euro & & & $\begin{array}{c}0.145 * * * \\
(6.30)\end{array}$ & $\begin{array}{c}0.293^{* * *} \\
(10.10)\end{array}$ & $\begin{array}{l}0.145 \\
(0.96)\end{array}$ & & \\
\hline Traditional CAC dummy - Dollar & & & $\begin{array}{c}0.342^{* * *} \\
(6.87)\end{array}$ & $\begin{array}{c}0.460^{* * *} \\
(4.32)\end{array}$ & $\begin{array}{l}0.342 \\
(1.00)\end{array}$ & & \\
\hline ICMA CAC dummy - Euro & & & $\begin{array}{c}-1.002 * * * \\
(-15.98)\end{array}$ & $\begin{array}{c}-0.666^{* * *} \\
(-10.37)\end{array}$ & $\begin{array}{c}-1.002^{* * *} \\
(-4.56)\end{array}$ & & \\
\hline ICMA CAC dummy - Dollar & & & $\begin{array}{c}-0.0341 \\
(-0.42) \\
\end{array}$ & $\begin{array}{l}-0.0474 \\
(-0.27) \\
\end{array}$ & $\begin{array}{c}-0.0341 \\
(-0.07) \\
\end{array}$ & & \\
\hline Bond-level effect & $\mathrm{N}$ & Fixed & $\mathrm{N}$ & Fixed & Random & $\mathrm{N}$ & $\mathrm{N}$ \\
\hline Weekly fixed effects & $\mathrm{Y}$ & $\mathrm{Y}$ & $\mathrm{Y}$ & $\mathrm{N}$ & $\mathrm{Y}$ & $\mathrm{N}$ & $\mathrm{N}$ \\
\hline Numer of observations & 2466 & 2466 & 2466 & 2466 & 2466 & 1528 & 938 \\
\hline R-squared & 0.917 & 0.945 & 0.921 & 0.924 & - & 0.944 & 0.816 \\
\hline
\end{tabular}

$\frac{0.917}{\text { R-squared }}$ 
Table 8: Traditional vs. Enhanced CACs in Swedish sovereign bonds. Post-2013 sample

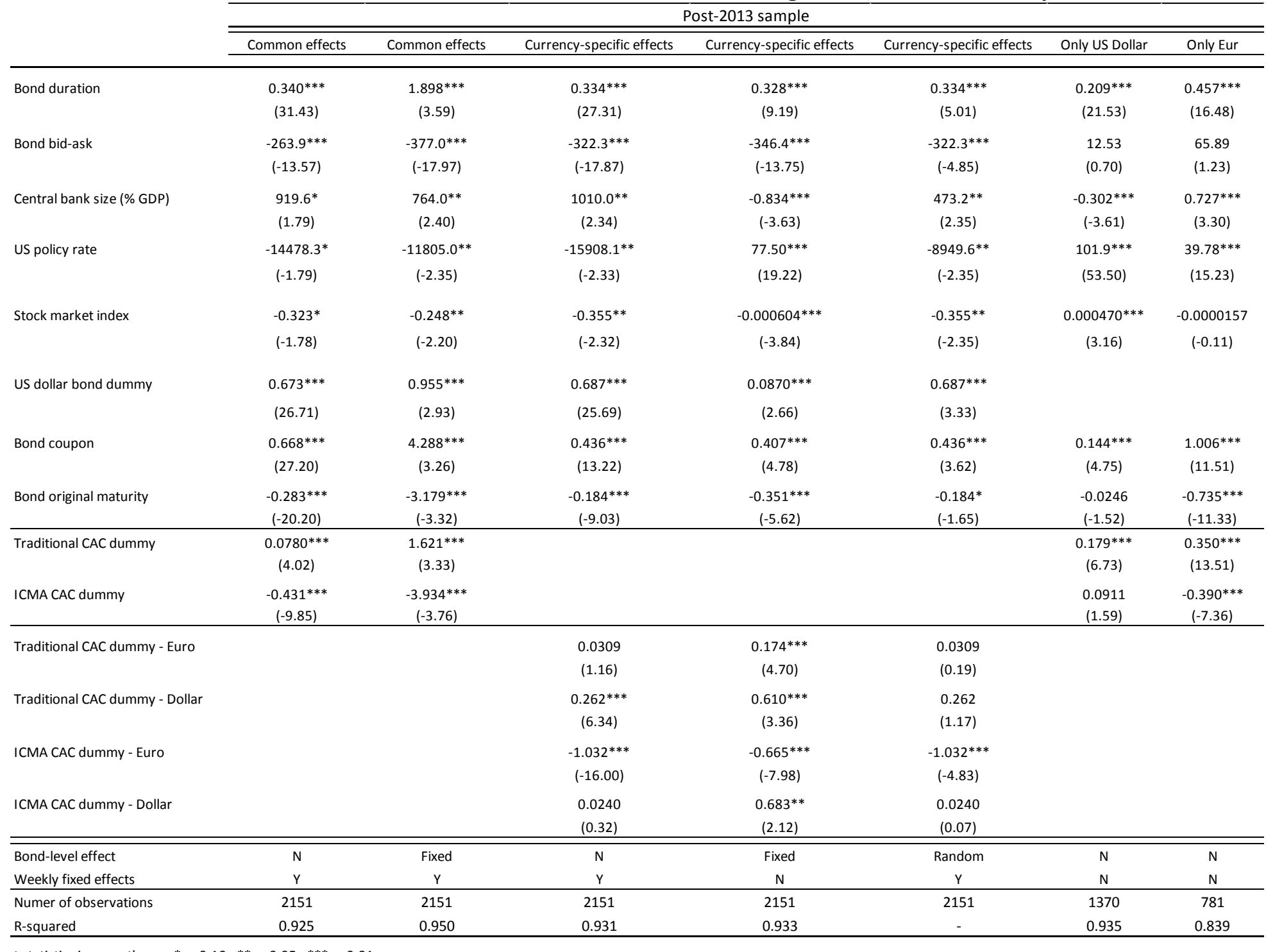

t statistics in parentheses. ${ }^{*} p<0.10, * * p<0.05, * * * p<0.01$ 